\title{
Baikalsky State Nature Biosphere Reserve and its buffer zone: floristic data
}

\author{
Natalia Sergeevna Gamova $\ddagger$, § \\ ‡ Herbarium (MW), Faculty of Biology, M. V. Lomonosov Moscow State University, Moscow, Russia \\ $\S$ Baikalsky State Nature Biosphere Reserve, Tankhoy, Russia
}

Corresponding author: Natalia Sergeevna Gamova (bg natagamova@mail.ru)

Academic editor: Alexander Sennikov

Received: 23 Oct 2021 | Accepted: 31 Dec 2021 | Published: 06 Jan 2022

Citation: Gamova NS (2022) Baikalsky State Nature Biosphere Reserve and its buffer zone: floristic data.

Biodiversity Data Journal 10: e76946. https://doi.org/10.3897/BDJ.10.e76946

\begin{abstract}
Background

Baikalsky State Nature Biosphere Reserve is situated in the central part of the KhamarDaban Range (Southern Baikal, Siberia), in three administrative districts of Republic of Buryatia (i.e. Kabansky District, Dzhidinsky District and Selenginsky District), Russia. In general, this territory has been relatively well studied by botanists, but until now there was no detailed information about the flora of the Reserve with precise geographic localities. Moreover, some records in the Baikalsky Reserve's flora were published without references to documenting herbarium specimens.
\end{abstract}

\section{New information}

The dataset contains 39,238 unique occurrences of 875 taxa (854 species, 14 subspecies, five varieties and two species aggregates) from the Baikalsky Reserve and its buffer zone. All the data were acquired during the field studies by the author in 2009-2021, when 152 taxa $(17.3 \%$ of all the taxa included into the dataset) were first recorded by the author from the study area. Herbarium vouchers are preserved in the Moscow University Herbarium $(\mathrm{MW})$. This dataset is the first attempt at creating a database of vascular plants of the 
Baikalsky Reserve and its buffer zone, based on modern research. These data will provide the background for the updated check-list of the Baikalsky Reserve's flora.

\section{Keywords}

vascular plants, occurrence, Khamar-Daban Range, Republic of Buryatia, Russia

\section{Introduction}

Baikalsky Reserve was established in 1969 to protect local plant communities of the Khamar-Daban Range within all the altitudinal zones. The Baikalsky Reserve's flora includes several relict plant species (Epova 1956, Chepinoga et al. 2017b). To protect the unique natural complexes of this area, Baikalsky Reserve was assigned the status of Biosphere Reserve in 1986. Therefore, a special buffer zone surrounding its borders was created (buffer zone is obligatory for all the Biosphere Reserves in Russia). The Baikalsky Reserve is one of the key natural protected areas in the system of nature conservation in southern Siberia. The Reserve is also a part of the Lake Baikal World Heritage Site since 1996 (Unesco World Heritage Center (2021)).

First detailed botanical studies here began in the middle of the $20^{\text {th }}$ century. Scientists from Irkutsk described the vegetation of the Khamar-Daban Range and collected herbarium specimens (herbarium vouchers are preserved now in the Herbaria IRK and IRKU). N.A. Epova studied the vegetation and relict species and made the first map of floristic division of this territory (Epova 1956, Epova 1957, Epova 1960, Epova 1961). M.M. Ivanova continued this work and also explored the alpine flora of the Khamar-Daban Range (Ivanova 1967). The first check-list of vascular plants of the Baikalsky Reserve was published in 1978 (Vasilchenko et al. 1978) and contained 777 taxa. Floristic investigations continued and several additions to the flora were published later (Volotovsky and Ermolenko 1985, Ivanova 1991, Krasnopevtseva et al. 2008a). The second check-list was published in 2008 (Krasnopevtseva et al. 2008b) and contained 886 taxa; new additions followed soon (Abramova et al. 2009). The third check-list, including 991 taxa, was published in 2011 (Abramova and Volkova 2011). Several additions to the flora of the Baikalsky Reserve and its buffer zone were published since 2011 (Gamova and Dudov 2012, Krasnopevtseva and Krasnopevtseva 2012, Gamova and Krasnopevtseva 2013, Verkhozina et al. 2013, Ivanova et al. 2016, Sutkin et al. 2016, Tupitsyna and Chepinoga 2016, Gamova and Dudov 2018a, Gamova and Dudov 2018b, Gamova et al. 2018a, Gamova et al. 2018b, Chepinoga et al. 2019, Gamova et al. 2019, Sutkin and Krasnopevtseva 2020). In 2009-2021, 152 new taxa were first recorded by the author and added to the flora of the Baikalsky Reserve and its buffer zone. For other 18 new taxa, firstly found in recent years by other botanists, the author has recorded new localities.

Open-access data with precise geographic references are essential for modern research as it allows a computational approach to analysing spatial patterns of species distributions. This is the first comprehensive dataset focusing on the flora of the Baikalsky Reserve 
covering its whole territory and all the taxonomic groups of vascular plants. Several datasets, including some data from the territory of the Baikalsky Reserve amongst other areas, were published in recent years (Chepinoga et al. 2017a, Brianskaia et al. 2021, Seregin 2021). However, these datasets focused on various aspects, namely on the distribution of alpine endemic plants of northern Asia, on digitising grid maps from the "Flora of Central Siberia" (1979) or on digitising herbarium collections of Moscow State University, neither of them aimed at thoroughly studying the Baikalsky Reserve's flora. Thus, the aim of the present work is to narrow this gap in the knowledge of the vascular plant species distributions in the Baikalsky Reserve.

\section{General description}

Purpose: The main purpose of the dataset (Gamova 2021) is to give access to the modern floristic data from the Baikalsky Reserve, which is situated in a hard-to-reach area in the central part of the Khamar-Daban Range and to study the plant diversity of this territory. Systematic data collection enabled us to reveal the local species richness.

Additional information: The dataset contains 39,238 occurrences from 3,156 sampling events. A total of $90.39 \%$ of the dataset $(35,467$ occurrences) is formed by species lists from 1,873 relevés $(59.35 \%$ of all sampling events). The number of species per one relevé varies from 8 to 87 , with 19 species on average.

The flora of the Baikalsky Reserve has been actively studied since the Reserve was established, but only recently has it become possible to create a database containing exact geographic localities. Furthermore, both current species distributions and full check-list of the flora of the Baikalsky Reserve may require further verification.

The dataset aims at biodiversity monitoring and inventory in the framework of scientific research in the Baikalsky Reserve. This dataset does not cover a full list of vascular plants of the Baikalsky Reserve. It contains the data collected only by the author during her own field research. All the herbarium vouchers preserved at the Moscow University Herbarium (MW) have been made available online via GBIF (Seregin 2021). All findings of the taxa reported by the author for the first time for the Baikalsky Reserve and its buffer zone are documented with herbarium vouchers. This herbarium collection contains both common and rare species from the territory (Fig. 1).

At present, the dataset contains 875 taxa at species and infraspecific levels. This is approximately 280 species less than in our preliminary unpublished check-list of the Baikalsky Reserve's flora which includes all records from all the published sources. Revisiting the herbarium collections in Irkutsk, Ulan-Ude and Tomsk revealed that ca. 150 species out of these 280 have never been documented by herbarium vouchers and their publications cannot be confirmed. All the herbarium specimens from our territory kept at the Novosibirsk Herbarium were mentioned in the check-list of the flora of Baikal's shores (Popov and Busik 1966), lacking the aforementioned 150 species, as well. Therefore, published reports without herbarium vouchers should be interpreted with caution. To date, 
only some records were rejected after our re-examination of herbarium specimens when original identifications were erroneous; for example, Achnatherum splendens, Carex selengensis, Hypericum ascyron etc. were re-identified and those species were excluded (Gamova et al. 2019) from our preliminary check-list. The presence of other species mentioned in earlier publications, but not confirmed by herbarium specimens, will be further verified via fieldwork.

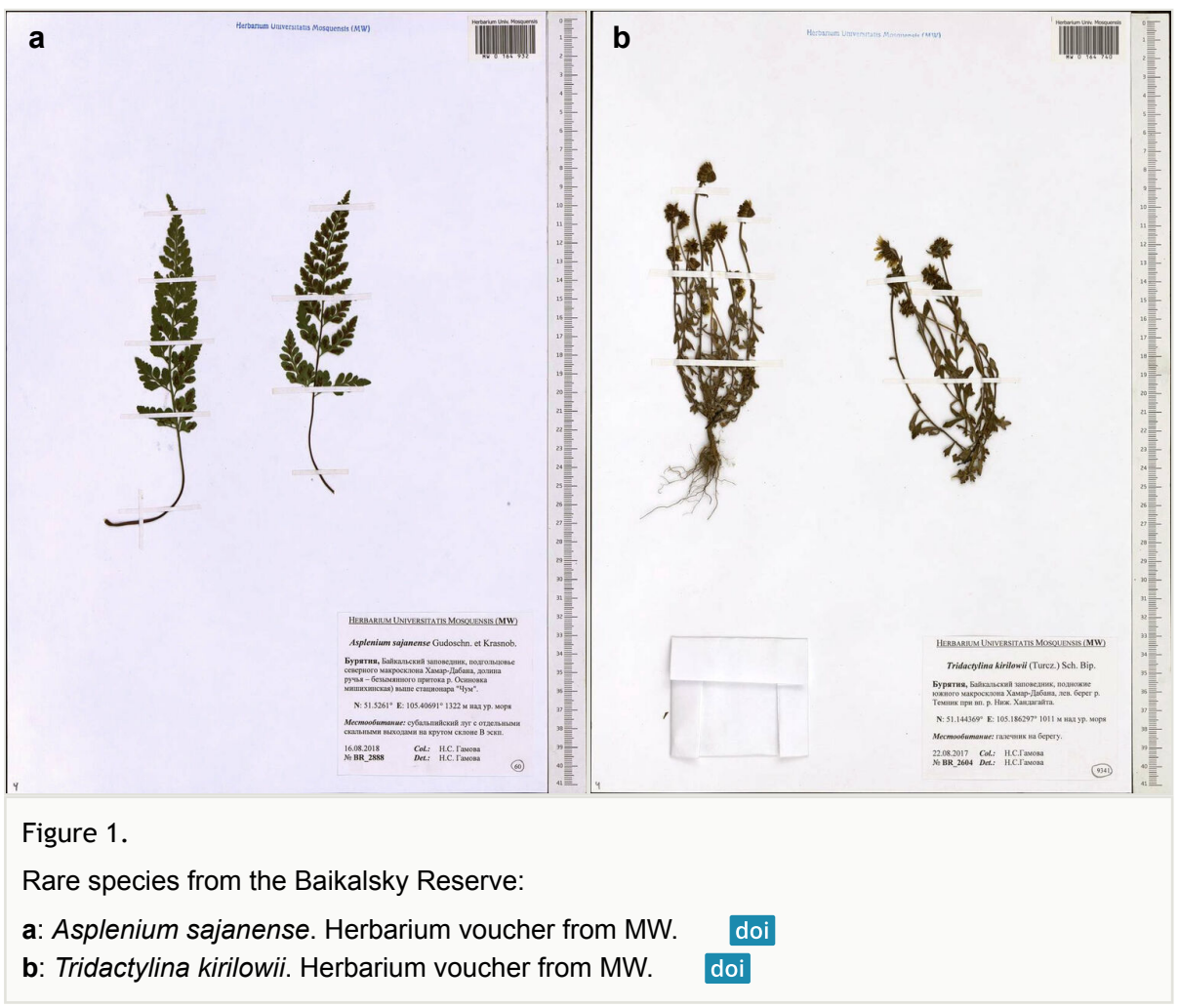

As the majority of herbarium specimens collected by other researchers and not included in this dataset date back to the middle of the $20^{\text {th }}$ century, they lack the geographic coordinates and the textual description of the locality does not allow georeferencing with the precision of $1-2 \mathrm{~km}$. Sometimes, the description is even more vague and the uncertainty reaches $5-10 \mathrm{~km}$. Approximately 30 species, recently recorded by other researchers and confirmed by herbarium specimens with geographic coordinates and, therefore, suitable for this type of dataset, were not included. Thus, the dataset with the original data collected by the author contains the majority of vascular plant species authentically known from Baikalsky Reserve and its buffer zone.

At the moment, a new check-list of the vascular plant flora of the Baikalsky Reserve, based on modern data and herbarium specimens, is being compiled. The data from the other herbaria will be further included into the updated check-list and georeferenced with the maximum available precision. 


\section{Sampling methods}

Study extent: The Baikalsky Reserve with its buffer zone is situated mostly in the mountains. The lowest point of this territory is situated on the Baikal shore (457 $\mathrm{m}$ a.s.l.) and the highest point is Mt. Sokhor (2,316.7 $\mathrm{m}$ a.s.l.) in the middle part of the Baikalsky Reserve. The Temnik River forms the southern border of the Baikalsky Reserve $(1,100$ $830 \mathrm{~m}$ a.s.l. from west to east). Altogether the territory of the Baikalsky Reserve and its buffer zone covers ca. $2,000 \mathrm{~km}^{2}(167,871$ ha and 34,788 ha, respectively).

The Khamar-Daban Range is one of the mountain chains framing Lake Baikal in its rift zone; its origin dates back to the Baikal Orogeny (650-550 million years). Despite the ancient age, alpine landforms are widespread here due to mountain glaciation. The territory of the Baikalsky Reserve belongs to the area with local distribution of permafrost; some permafrost spots are located in the highlands and on the southern side (Gerasimov 1965).

The climate of the northern side of the Khamar-Daban Range in its central part is relatively mild for southern Siberia. The mean annual temperatures vary from $-0.3^{\circ} \mathrm{C}$ at Tankhoy meteostation ( $460 \mathrm{~m}$ a.s.I.) to $-3.4^{\circ} \mathrm{C}$ at the Khamar-Daban meteostation (1,420 $\mathrm{m}$ a.s.I.). The mean July temperatures are $+14.7^{\circ} \mathrm{C}$ and $+12.7^{\circ} \mathrm{C}$; the mean January temperatures are $-17^{\circ} \mathrm{C}$ and $-17.9^{\circ} \mathrm{C}$, correspondingly. The mean annual amount of precipitation is 900 $1,450 \mathrm{~mm}$. Winter snow cover reaches at least $90-100 \mathrm{~cm}$ with an average depth of 150 $\mathrm{cm}$ and the maximum depth of 190-200 cm (Ladeishchikov et al. 1977). Both the annual amount of precipitation and the winter snow cover in the central part of the northern side of the Khamar-Daban Range are the maximal in the Baikal Region. The climate of the southern side is drier (400-600 $\mathrm{mm}$ annual precipitation) and more continental. The mean annual temperature here is about $-5^{\circ} \mathrm{C}$; the mean July temperature is $+12^{\circ} \mathrm{C}$ and the mean January temperature is $-22^{\circ} \mathrm{C}$. The average duration of the vegetation period varies from 120-150 days on the Baikal shore to 100 days on the main watershed of the KhamarDaban Range (Kartushin 1969).

According to "Zones and altitudinal zonality types of vegetation of Russia and adjacent territories", the study area within the central part of the Khamar-Daban Range belongs to the Khamar-Daban variant (Abies sibirica and Pinus sibirica forests, Pinus pumila elfin woods) of Tuva-Southern Transbaical group (nival-goltsy-tundra-taiga) of the Boreal (Taiga) type of altitudinal zonality (Ogureeva et al. 1999). The territory of the Baikalsky Reserve includes all the diversity of local altitudinal zonality (Epova 1957, Epova 1961, Tjulina 1976). The northern side is covered by coniferous forests (Siberian taiga with Pinus sibirica and Abies sibirica) in its main part. Subalpine meadows and elfin woods of dwarf Siberian pine (Pinus pumila) are situated above the timber line. Vegetation of the main watershed of the Khamar-Daban Range consists mostly of mountain tundra and alpine meadows. The altitudinal zonality of the southern side is presented by three main vegetation belts. Subalpine meadows are less presented here and Pinus pumila elfin woods are well-developed. The upper forest belt here is presented by Pinus sibirica, while the most part of the southern side is covered by larch taiga (Larix sibirica) and its lower 
part - by pine taiga (Pinus sylvestris). Some local stations of steep rocky slopes in the valley of the Temnik River are very dry and steppe plant communities are situated here. In addition, there are forests (including secondary ones) with bogs and meadows which are widespread along the Baikal shores. Intrazonal vegetation of river valleys is represented by mixed polydominant forests with Populus suaveolens mostly on the northern side of the Khamar-Daban Range.

The flora of the Khamar-Daban Range belongs to the Altay-Sayan Province of the Circumboreal Region of the Boreal (Holarctic) floristic kingdom, following Takhtajan (1986). The flora of the Baikalsky Reserve and its buffer zone by its origin consists of two main parts: native species and alien ones. Although the alien section of the flora reaches ca. $120-130$ species $(12 \%$ of total flora), it is concentrated in the narrow belt $(0.5-4 \mathrm{~km})$ of the buffer zone adjacent to the northern border of the Baikalsky Reserve near the Baikal shore. Several settlements (the major one is Tankhoy, a village with ca. 950 inhabitants, where the headquarters of the Baikalsky Reserve are situated), roads (highway Irkutsk - UlanUde and the Trans-Siberian Railway) and communications (power transmission line) are situated also in the northern part of the buffer zone near Baikal. The western, southern and eastern parts of the buffer zone of the Baikalsky Reserve are situated in the mountains and are not anthropogenically disturbed. According to the "Atlas of Russia's intact forest landscapes" (Aksenov et al. 2003), the core zone of the Baikalsky Reserve is formally classified as intact. The world map of intact forest landscapes (Potapov et al. 2021) indicating forest losses in 2000-2013, 2013-2016 and 2016-2020, shows that no significant changes in the forest cover occurred in the recent years. Therefore, alien species are not widespread here. Only less than 10 taxa of alien species (Chaenorhinum minus, Conyza canadensis, Epilobium adenocaulon, E. pseudorubescens, Impatiens glandulifera, Puccinellia hauptiana, Senecio viscosus, S. vulgaris) are relatively common (or have become common in recent years) in the buffer zone of Baikalsky Reserve, while the majority of them have rare or single occurrences (Gamova et al. 2018b). The flora of the Baikalsky Reserve includes several endemic or sub-endemic species. One of the most famous endemic species is Swertia baicalensis (Gentianaceae). It is known only from the western and central parts of the Khamar-Daban Range and the Baikalsky Reserve protects the main part of its distribution area. One of the new taxa - Eranthis tanhoensis (Ranunculaceae) - was described in 2020 (Erst et al. 2020). This species was named after Tankhoy Village. It is also an endemic of southern Baikal Region (Fig. 2).

Sampling description: All the data were obtained during fieldwork in summer seasons 2009-2021 (except 2020 due to the COVID-related lockdown), mostly between 10 June and 20-25 August, in some years also including the beginning of September. This time interval covers the major part of the vegetation development in this region. Ephemerous plant species are absent from the Baikalsky Reserve and ephemeroid plants begin to flower in May and continue in June. All of them remain noticeable until mid-July or August; thus, this group of species is adequately represented in the dataset. In general, the field works were conducted during 2-2.5 months per year, except 2011 when field data were collected only for three weeks. 

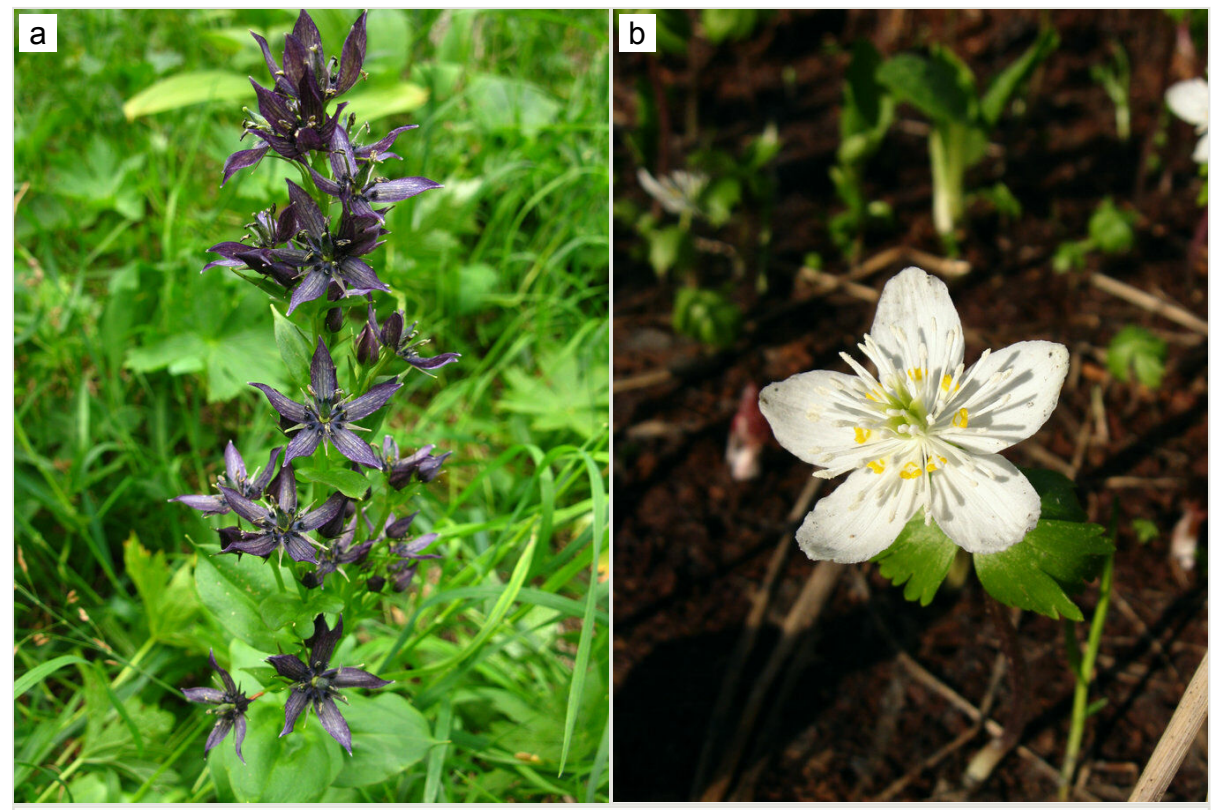

Figure 2.

Endemics of southern Baikal Region:

a: Swertia baicalensis. Photo by the author. doi

b: Eranthis tanhoensis. Photo by the author. doi

The dataset contains information from different sources:

1. Relevés made in various altitude belts and plant communities. The locations for the relevés were chosen carefully within the contours of homogeneous plant communities. The area of the relevés was $400 \mathrm{~m}^{2}$ for forest communities and 100 $\mathrm{m}^{2}$ for herbaceous ones. If the area of the plant community was less than those mentioned above, the community was described within its natural limits. The original data also contain additional information on the projective cover of species etc., but only the species list was included in the dataset.

2. Plants collected as herbarium specimens. In all the cases, when species identification in the field was impossible and/or new taxa for the Baikalsky Reserve were recorded, specimens were preserved.

3. Field notes about plant occurrences. Additional localities for particular species, mostly rare and endangered ones, or remarkable localities for common species (for example, single trees above the timber line etc.).

The research was conducted systematically, the field routes being planned to access the maximal coverage of different parts of the Baikalsky Reserve and its buffer zone. The major part of the Baikalsky Reserve's territory is located in the mountains. The only highway (Irkutsk - Ulan-Ude) is situated north of Baikalsky Reserve. As the rest of the territory is inaccessible for motor transport, it was explored mostly on foot; pack horses were also used on the lower part of the southern side and half of the length of the Temnik 
River is accessible via airboat. Within the borders of the Baikalsky Reserve, four mountain passes (1,400-2,220 m a.s.I.) across the Khamar-Daban Range are predominantly used. The majority of paths follow the river valleys. To evenly study the territory, the routes were planned along the paths and radially around field camp sites. The total length of field routes comprised ca. $320 \mathrm{~km}$ in 2021; in the other years, it varied from $180 \mathrm{~km}$ to $420 \mathrm{~km}$.

All the data reflect the spontaneous distribution of plants, both native and alien species. Cultivated plants from Tankhoy Village and other minor populated places situated in the buffer zone of the Baikalsky Reserve are not included into the dataset.

Quality control: All the localities were georeferenced in the field via portable GPSnavigators Garmin (Etrex H in 2009-2017 and GPSmap 64 st since 2018), so the accuracy of the coordinates was limited by the technical characteristics of the devices.

Most of the plant identifications were made by the author, but there are several cases in specific taxonomic groups, in which identification was made by taxonomic experts and local florists. These are the following taxa: Boraginaceae, Chenopodiaceae, Artemisia, Calamagrostis, Carex, Epilobium, Hieracium, Oxytropis, Persicaria, Pilosella, Poa, Polygonum, Potamogeton and Salix. As a result, 37,532 occurrences $(95.65 \%$ of the dataset) were identified to the species or infraspecific levels and 274 occurrences $(0.7 \%)$ were referred to two species aggregates, i.e. Festuca ovina and Taraxacum officinale.

To reveal the local vascular plant diversity to its full extent, the occurences, identified to the genus level, were also included into the dataset (i.e. 1432 occurrences or $3.65 \%$ of the dataset, for 53 genera). Alchemilla, Euphorbia, Hedysarum, Lepidium, Sinapis, Sparganium and Valeriana were identified to the genus level only. Other 46 genera have occurrences both at species and genus levels. These are mostly Allium, Betula, Calamagrostis, Carex, Salix and some others. In most cases, though, the choice for unidentified species could be considerably narrowed to a certain selection according to the check-lists of the flora of the Republic of Buryatia and Irkutsk Region (Anenkhonov et al. 2001, Chepinoga et al. 2008); such variants are mentioned below in alphabetical order of genera. Cases, where too many options are possible due to the species richness within the genus (as in genera Carex and Salix) or where new alien species can be found (Alchemilla ) or for some other reasons, are noted as "unknown".

Achillea: Ptarmica group. Aconitum: blue-flowered species (A. ambiguum, A. baicalense, A. glandulosum; perhaps some others). Agrostis: A. clavata, A. tenuis; perhaps A. trinii. Alchemilla: unknown; this group needs a special revision in Baikal Region due to recent findings of several alien species. Allium: non-flowering plants of $A$. splendens and $A$. strictum; A. amphibolum, A. malyschevii, perhaps some others, depending on habitat and altitude. Alopecurus: non-flowering plants, most possibly A. arundinaceus. Aquilegia: nonflowering plants of $A$. glandulosa or $A$. sibirica. Avena: most possibly A. fatua or $A$. sativa, perhaps some other alien species. Betula: $B$. pubescens or $B$. platyphylla in cases, where key features for identification were not available. Brassica: unknown; except $B$. campestris; possibly, B. juncea. Calamagrostis: C. arundinacea, C. lapponica, C. neglecta, C. pavlovii, C. tenuis, depending on habitat and altitude. Carex: unknown. Cerastium: mostly alpine 
species; C. flavescens, C. pusillum, perhaps some others. Chenopodium: unknown, other than C. album. Deschampsia: unknown, other than D. cespitosa. Elymus: E. caninus, E. confusus, E. mutabilis, E. transbaicalensis. Eriophorum: alpine species; most possibly $E$. brachyantherum, E. gracile, E. humile, perhaps some others. Euphorbia: either E. borealis or E. discolor. Euphrasia: most possibly E. pectinata or E. stricta. Gastrolychnis: unknown. Glyceria: G. lithuanica, G. plicata, G. spiculosa, G. triflora. Gymnocarpium: either G. dryopteris or $G$. jessoense. Hedysarum: $H$. alpinum, $H$. inundatum, $H$. neglectum, perhaps some others. Hieracium: unknown. Hierochloe: possibly $H$. odorata or H. glabra. Huperzia: alpine plants different from $H$. selago s.str.; perhaps, $H$. appressa. Lappula: $L$. redowskii or L. squarrosa. Lepidium: unknown; possibly, L. densiflorum or L. virginianum. Lonicera: either $L$. caerulea subsp. pallasii or $L$. caerulea subsp. altaica; all plants from the southern macroslope, due to uncertainty of features in many cases. Luzula: alpine species, other than L. kamtschadalorum. Lycopodium: either L. clavatum or L. lagopus in subalpine zone. Myosotis: unknown, other than $M$. cespitosa, M. imitata or M. scorpioides. Pilosella: unknown. Plantago: P. depressa, P. major or P. media. Poa: non-flowering plants; most possibly species within the list of species mentioned in the dataset. Potamogeton: unknown; most possibly species within the list of species mentioned in the dataset. Pulsatilla: other than P. orientali-sibirica or P. turczaninovii; perhaps, P. bungeana. Pyrola: non-flowering plants, most possibly $P$. incarnata or $P$. minor. Ranunculus: most possibly $R$. polyanthemos or $R$. propinquus; perhaps some other species close to these two. Rhizomatopteris: either R. montana or R. sudetica. Salix: unknown shrub species, most possibly others than mentioned in the dataset. Saussurea: S. latifolia or S. parviflora in habitats where both species can possibly occur. Sinapis: $S$. alba or $S$. arvensis. Sparganium: unknown. Spiraea: non-flowering plants of either $S$. flexuosa or $S$. media. Stellaria: alpine species, unknown. Taraxacum: local alpine species, possibly $T$. ceratophorum, T. mongolicum. Trisetum: T. agrostideum or T. altaicum for alpine habitats; for others most possibly $T$. sibiricum. Urtica: most possibly, U. dioica or $U$. galeopsifolia. Valeriana: V. alternifolia (if separated from V. officinalis) or V. transjenisensis. Vicia, Viola: species within the list of mentioned in the dataset. Woodsia: unknown; most possibly others than $W$. ilvensis; perhaps W. glabella, W. calcarea or some other species.

\section{Geographic coverage}

Description: In general, all the territory of the Baikalsky Reserve and its buffer zone is covered by our field routes. The records are concentrated mainly along the paths and river valleys or some localities of particular botanical interest (Fig. 3).

Coordinates: 51.1 and 51.7 Latitude; 104.8 and 105.6 Longitude.

\section{Taxonomic coverage}

Description: The dataset includes all the Tracheophyta found in the Baikalsky Reserve and its buffer zone. The majority of occurrences belong to Magnoliopsida $(25,580$ or $65.19 \%$ ); Liliopsida has 6,979 occurrences (17.79\%), Pinopsida - 3,678 occurrences 
(9.38\%), Polypodiopsida - 2,430 occurrences (6.19\%), Lycopodiopsida - 564 occurrences $(1.44 \%)$, and Gnetopsida (with its only member Ephedra monosperma) - seven occurrences $(0.01 \%)$.

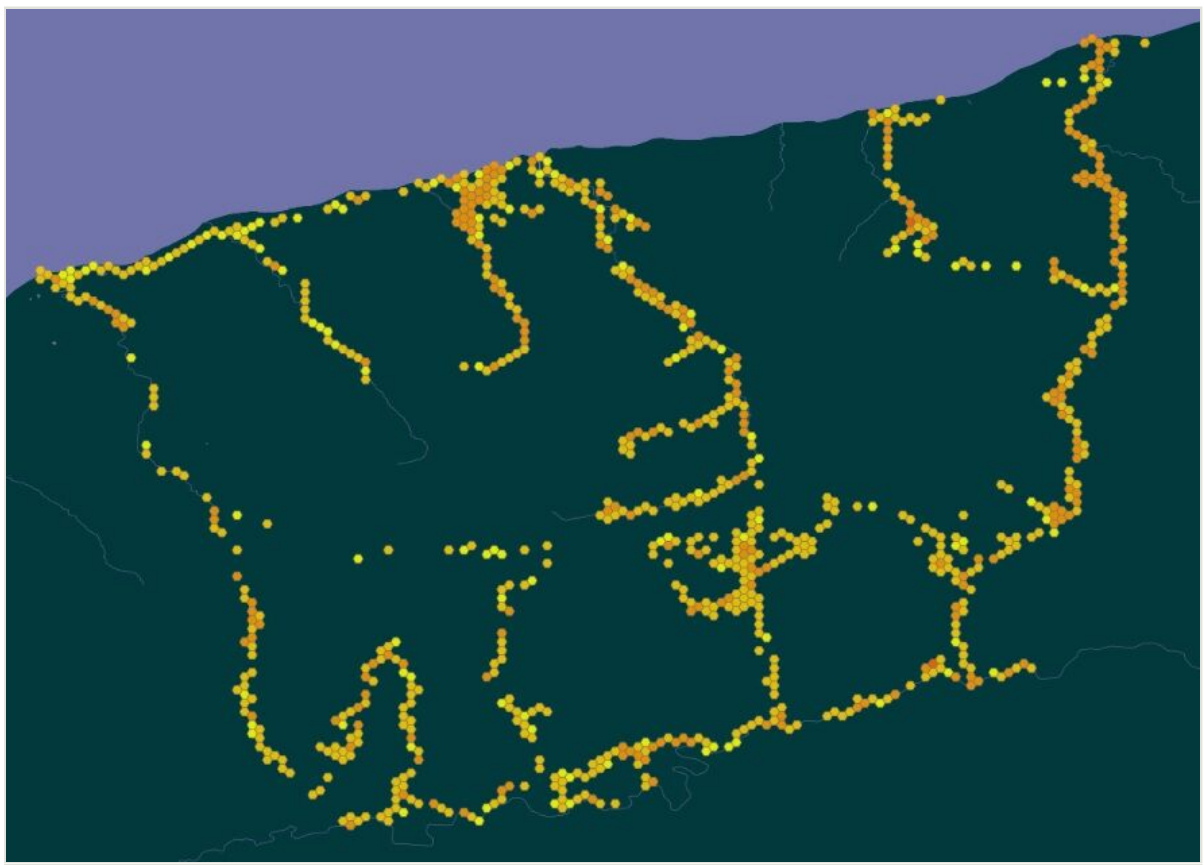

Figure 3. doi

Geographic coverage of records within the dataset (Baikalsky State Nature Biosphere Reserve and its buffer zone: floristic data available via GBIF on https://doi.org/10.15468/ g4sdvs).

The taxa included into the dataset belong to 410 genera of 89 plant families. Top-10 families with the largest numbers of taxa at the species or infraspecific level and the largest number of occurrences are mentioned in Tables 1,2. The taxa from the top-10 plant families shown in Table 1 include 502 taxa (57.37\% of the taxonomic diversity included into the dataset). The occurrences of plants from the top-10 plant families shown in Table 2 include 23,272 occurrences (59.31\% of the dataset).

Table 1.

Top-10 families with the largest number of taxa on species and infraspecific level.

\begin{tabular}{|l|l|l|l|}
\hline Rank & Family & Number of taxa & $\%$ of taxa of the dataset \\
\hline 1 & Asteraceae & 103 & 11.77 \\
\hline 2 & Poaceae & 91 & 10.40 \\
\hline 3 & Cyperaceae & 58 & 6.63 \\
\hline
\end{tabular}




\begin{tabular}{|l|l|l|l|}
\hline Rank & Family & Number of taxa & $\%$ of taxa of the dataset \\
\hline 4 & Rosaceae & 50 & 5.71 \\
\hline 5 & Fabaceae & 44 & 5.03 \\
\hline 6 & Ranunculaceae & 39 & 4.46 \\
\hline 7 & Caryophyllaceae & 36 & 4.11 \\
\hline 8 & Brassicaceae & 34 & 3.89 \\
\hline 9 & Ericaceae & 24 & 2.74 \\
\hline 10 & Apiaceae & 23 & 2.63 \\
\hline
\end{tabular}

Table 2.

Top-10 families with the largest number of occurrences

\begin{tabular}{|l|l|l|l|}
\hline Rank & Family & Number of occurrences & \% of records of the dataset \\
\hline 1 & Pinaceae & 3534 & 9.01 \\
\hline 2 & Poaceae & 3331 & 8.49 \\
\hline 3 & Asteraceae & 3275 & 8.35 \\
\hline 4 & Rosaceae & 3149 & 8.03 \\
\hline 5 & Ericaceae & 2677 & 6.82 \\
\hline 6 & Ranunculaceae & 2300 & 5.86 \\
\hline 7 & Betulaceae & 1579 & 4.02 \\
\hline 8 & Cyperaceae & 1252 & 3.19 \\
\hline 9 & Fabaceae & 1154 & 2.94 \\
\hline 10 & Apiaceae & 1021 & 2.60 \\
\hline
\end{tabular}

Although Pinaceae does not belong to the top-10 plant families with the largest number of taxa, it has the largest number of occurrences $(3,534)$ in the dataset.

Taxa included:

\begin{tabular}{|l|l|}
\hline Rank & Scientific Name \\
\hline phylum & Tracheophyta \\
\hline
\end{tabular}

\section{Temporal coverage}

Data range: 2009-6-25 - 2021-8-30.

Notes: Distribution of records by year is shown in Fig. 4. 


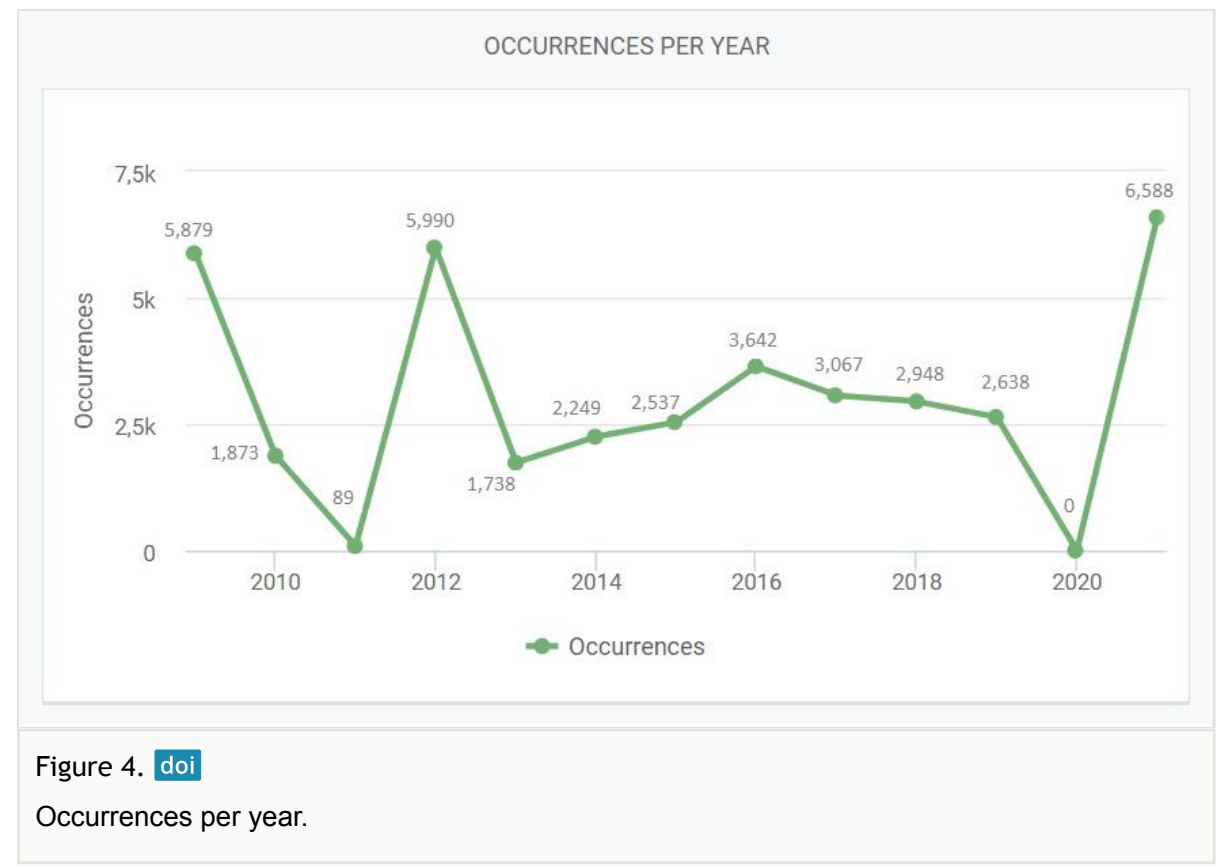

\section{Usage licence}

Usage licence: Creative Commons Public Domain Waiver (CC-Zero)

IP rights notes: This work is licensed under a Creative Commons Attribution (CC-BY) 4.0 License.

\section{Data resources}

Data package title: Baikalsky State Nature Biosphere Reserve and its buffer zone: floristic data

\section{Resource link: https://doi.org/10.15468/g4sdvs}

Alternative identifiers: $10.15468 / g 4 s d v s, 11512 f e 2-50 c f-48 e 1-b 681-3 b b 1 f 347 e b 86$, https://depo.msu.ru/ipt/resource?r=baikal

\section{Number of data sets: 1}

Data set name: Baikalsky State Nature Biosphere Reserve and its buffer zone: floristic data

Data format: Darwin Core

Description: The dataset contains records on vascular plants from Baikalsky State Nature Biosphere Reserve and its buffer zone. The Reserve is situated in three 
admimistrative districts of Republic of Buryatia (i.e. Kabansky District, Dzhidinsky District and Selenginsky District), Russia. Field data were obtained in 2009-2021. Herbarium vouchers are preserved in Moscow University Herbarium (MW).

\begin{tabular}{|c|c|}
\hline Column label & Column description \\
\hline occurrencelD & $\begin{array}{l}\text { An identifier for the occurrence. A variable constructed from a combination of two } \\
\text { identifiers (datasetID and catalogNumber). For example, "urn:Isid:biocol.org:col: } \\
\text { 15550:12:00001". }\end{array}$ \\
\hline dcterms:type & The nature or genre of the resource. A constant ("Dataset"). \\
\hline dcterms:modified & $\begin{array}{l}\text { The most recent date-time on which the resource was changed. A constant } \\
\text { ("2021-11-25"). }\end{array}$ \\
\hline dcterms:language & A language of the resource. A constant ("en" = English) \\
\hline dcterms:licence & $\begin{array}{l}\text { A legal document giving official permission to do something with the resource. A } \\
\text { constant. ("http://creativecommons.org/licenses/by/4.0/legalcode") }\end{array}$ \\
\hline dcterms:rightsHolder & $\begin{array}{l}\text { A person or organisation owning or managing rights over the resource. A constant } \\
\text { ("Moscow State University"). }\end{array}$ \\
\hline dcterms:accessRights & $\begin{array}{l}\text { Information about who can access the resource or an indication of its security } \\
\text { status. A constant ("Use under CC BY 4.0"). }\end{array}$ \\
\hline institutionID & $\begin{array}{l}\text { An identifier for the institution having custody of the object(s) or information } \\
\text { referred to in the record. A constant ("http://grbio.org/institution/moscow- } \\
\text { stateuniversity" for the Moscow State University). }\end{array}$ \\
\hline collectionID & $\begin{array}{l}\text { An identifier for the collection or dataset from which the record was derived. A } \\
\text { constant ("urn:Isid:biocol.org:col:15550" for the Moscow University Herbarium). }\end{array}$ \\
\hline datasetID & $\begin{array}{l}\text { An identifier for the set of data. May be a global unique identifier or an identifier } \\
\text { specific to a collection or institution. A constant ("urn:Isid:biocol.org:col:15550:12"). }\end{array}$ \\
\hline institutionCode & $\begin{array}{l}\text { The name (or acronym) in use by the institution having custody of the object(s) or } \\
\text { information referred to in the record. A constant ("Moscow State University"). }\end{array}$ \\
\hline datasetName & $\begin{array}{l}\text { The name identifying the dataset from which the record was derived. A constant } \\
\text { ("Baikalsky State Nature Biosphere Reserve and its buffer zone: floristic data"). }\end{array}$ \\
\hline ownerInstitutionCode & $\begin{array}{l}\text { The name (or acronym) in use by the institution having ownership of the object(s) } \\
\text { or information referred to in the record. A constant ("Moscow State University"). }\end{array}$ \\
\hline basisOfRecord & $\begin{array}{l}\text { The specific nature of the data record - a subtype of the dcterms:type. A constant } \\
\text { ("HumanObservation"). }\end{array}$ \\
\hline informationWithheld & $\begin{array}{l}\text { Additional information that exists, but that has not been shared in the given record. } \\
\text { A variable. For example, "Associated ecological data and frequency estimate", } \\
\text { "Voucher reference". }\end{array}$ \\
\hline catalogNumber & $\begin{array}{l}\text { An identifier (preferably unique) for the record within the dataset or collection. A } \\
\text { variable. For example, "00001". }\end{array}$ \\
\hline
\end{tabular}




\begin{tabular}{|c|c|}
\hline recordedBy & $\begin{array}{l}\text { A list (concatenated and separated) of names of people, groups or organisations } \\
\text { responsible for recording the original occurrence. A constant ("Natalia S. } \\
\text { Gamova"). }\end{array}$ \\
\hline occurrenceStatus & $\begin{array}{l}\text { A statement about the presence or absence of a taxon at a location. A constant } \\
\text { ("present"). }\end{array}$ \\
\hline eventID & $\begin{array}{l}\text { An identifier for the set of information associated with an event. A variable. For } \\
\text { example, "2009-001". }\end{array}$ \\
\hline eventDate & The date when the event was recorded. A variable. For example, "2009-06-25". \\
\hline higherGeography & $\begin{array}{l}\text { A list (concatenated and separated) of geographic names less specific than the } \\
\text { information captured in the locality term. A constant ("Asia | Russian Federation | } \\
\text { Republic of Buryatia"). }\end{array}$ \\
\hline continent & The name of the continent in which the location occurs. A constant ("Asia"). \\
\hline country & $\begin{array}{l}\text { The name of the country or major administrative unit in which the location occurs. } \\
\text { A constant ("Russian Federation"). }\end{array}$ \\
\hline countryCode & The standard code for the country in which the location occurs. A constant ("RU"). \\
\hline stateProvince & $\begin{array}{l}\text { The name of the next smaller administrative region than country (state, province, } \\
\text { canton, department, region etc.) in which the location occurs. A constant ("Republic } \\
\text { of Buryatia"). }\end{array}$ \\
\hline minimumElevationInMetres & $\begin{array}{l}\text { The lower limit of the range of elevation (altitude, above sea level), in m a.s.I. A } \\
\text { variable. For example, "648". }\end{array}$ \\
\hline decimalLatitude & $\begin{array}{l}\text { The geographic latitude (in decimal degrees, using the spatial reference system } \\
\text { given in geodeticDatum) of the geographic centre of a Location. A variable. For } \\
\text { example, "51.5670". }\end{array}$ \\
\hline decimalLongitude & $\begin{array}{l}\text { The geographic longitude (in decimal degrees, using the spatial reference system } \\
\text { given in geodeticDatum) of the geographic centre of a Location. A variable. For } \\
\text { example, "105.3956". }\end{array}$ \\
\hline geodeticDatum & $\begin{array}{l}\text { The ellipsoid, geodetic datum or spatial reference system (SRS) upon which the } \\
\text { geographic coordinates given in decimalLatitude and decimalLongitude are based. } \\
\text { A constant ("WGS84"). }\end{array}$ \\
\hline coordinateUncertaintyInMetres & $\begin{array}{l}\text { The horizontal distance (in metres) from the given decimalLatitude and } \\
\text { decimalLongitude describing the smallest circle containing the whole of the } \\
\text { location. A constant ("10"). }\end{array}$ \\
\hline coordinatePrecision & $\begin{array}{l}\text { A decimal representation of the precision of the coordinates given in the } \\
\text { decimalLatitude and decimalLongitude. A constant ("0.0001"). }\end{array}$ \\
\hline georeferencedBy & $\begin{array}{l}\text { A list (concatenated and separated) of names of people, groups or organisations } \\
\text { who determined the georeference (spatial representation) of the location. A } \\
\text { constant ("Natalia S. Gamova"). }\end{array}$ \\
\hline
\end{tabular}




\begin{tabular}{|c|c|}
\hline georeferencedDate & $\begin{array}{l}\text { Same as eventDate; georeferenced with GPS during observation. A variable. For } \\
\text { example, "2009-06-25". }\end{array}$ \\
\hline georeferenceSources & $\begin{array}{l}\text { A list (concatenated and separated) of maps, gazetteers or other resources used } \\
\text { to georeference the Location, described specifically enough to allow anyone in the } \\
\text { future to use the same resources. A constant ("field GPS data"). }\end{array}$ \\
\hline identifiedBy & $\begin{array}{l}\text { A list (concatenated and separated) of names of people, groups or organisations } \\
\text { who assigned the Taxon to the subject. A constant ("Natalia S. Gamova"). }\end{array}$ \\
\hline scientificName & $\begin{array}{l}\text { The full scientific name, with authorship and date information, if known. A variable. } \\
\text { For example, "Abies sibirica Ledeb.". }\end{array}$ \\
\hline kingdom & $\begin{array}{l}\text { The full scientific name of the kingdom in which the taxon is classified. A constant } \\
\text { ("Plantae"). }\end{array}$ \\
\hline phylum & $\begin{array}{l}\text { The full scientific name of the phylum or division in which the taxon is classified. A } \\
\text { constant ("Tracheophyta"). }\end{array}$ \\
\hline taxonRank & $\begin{array}{l}\text { The taxonomic rank of the most specific name in the scientificName. A variable } \\
\text { (five options: "species", "subspecies", "genus", "variety", "species aggregate"). }\end{array}$ \\
\hline nomenclaturalCode & $\begin{array}{l}\text { The nomenclatural code (or codes in the case of an ambiregnal name) under } \\
\text { which the scientificName is constructed. A constant ("International Code of } \\
\text { Nomenclature for algae, fungi and plants"). }\end{array}$ \\
\hline taxonomicStatus & $\begin{array}{l}\text { The status of the use of the scientificName as a label for a taxon. A constant } \\
\text { ("accepted"). }\end{array}$ \\
\hline
\end{tabular}

\section{Additional information}

Gamova N S (2021). Baikalsky State Nature Biosphere Reserve and its buffer zone: floristic data. Version 1.6. Lomonosov Moscow State University. Occurrence dataset https://doi.org/10.15468/g4sdvs accessed via GBIF.org on 2021-11-25.

\section{Acknowledgements}

The study was supported by the grant from Russian Science Foundation (project 21-77-20042).

I would like to acknowledge my colleagues who helped with identification of some groups of vascular plants: Dr. S.V. Dudov and Dr. M.N. Kozhin (Moscow State University) Calamagrostis, Carex, Salix, Poaceae; Dr. A.P. Seregin and Dr. S.R. Majorov (Moscow State University) - alien vascular plants; Dr. O.V. Jurtzeva (Moscow State University) Persicaria, Polygonum; Dr. A.P. Sukhorukov (Moscow State University) - Chenopodiaceae; Dr. A.A. Korobkov (Komarov Botanical Institute) - Artemisia; Dr. M.V. Olonova (Tomsk State University) - Poa; Dr. A.A. Bobrov (Papanin Institute for Biology of Inland Waters) Potamogeton; Dr. S.V. Ovchinnikova (Central Siberian Botanical Garden) - Lappula, 
Hackelia; Dr. A.N. Sennikov (Komarov Botanical Institute; University of Helsinki) and Dr. N.N. Tupitsyna (Krasnoyarsk State Pedagogical University) - Hieracium, Pilosella; Dr. R.E. Romanov (Komarov Botanical Institute) - Tillaea; Dr. N.V. Stepantsova (Irkutsk State University), Dr. N.V. Stepanov (Siberian Federal University), Dr. M.S. Knjazev (Botanical Garden UB RAS) and Dr. D.G. Chimitov (Institute of General and Experimental Biology SB RAS) - Oxytropis and some other local species.

Special thanks to the staff of the Baikalsky Reserve who supported my field work; to A.P. Seregin who helped with organising the dataset; to S.V. Dudov, M.N. Kozhin and T.M. Gavrilova (Moscow State University) who improved the text.

\section{Author contributions}

All stages of the work were performed by N.S. Gamova.

\section{References}

- Abramova LA, Volkova PA, Pykhalova TD, Anenkhonov OA (2009) Additions to the cadastre of flora of Baikalsky State Reserve. Turczaninowia 12 (1-2): 41-53. [In Russian]. URL: http://old.ssbg.asu.ru/turcz/turcz1_2_09 41_53.pdf

- $\quad$ Abramova LA, Volkova PA (2011) Сосудистые растения Байкальского заповедника (Аннотированный список видов). [Vascular plants of Baikalsky Reserve]. Flora and Fauna of Reserves, 117. Dobrosvet, Moscow, 112 pp. [In Russian]. URL: http://ashi punov.info/shipunov/school/books/abramova2011_sosud rast baik_zapov.pdf

- $\quad$ Aksenov DE, Dobrynin DV, Dubinin MJ, Yegorov AV, Isaev AS, Karpachevsky ML, Lestadius LG, Potapov PV, Purekhovsky AZ, Turubanov SA, Yaroshenko AJ (2003) Атлас малонарушенных лесных территорий России. [Atlas of Russia`s intact forest landscapes]. MCоЭC, Moscow, 177 pp. [In Russian]. URL: https://hcvf.ru/pub doc/all-rreprint2006-srgb.pdf [ISBN 5-88587-232-5]

- $\quad$ Anenkhonov OA, Pykhalova TD, Osipov KI, Sekulich IR, Badmayeva NK, Namzalov BB, Krivobokov LV, Munkueva MS, Sutkin AV, Tubshinova DB, D.Ya. T (2001) Определитель растений Бурятии. [Key for plants of Buryatia]. OAO «Республиканская типография», Ulan-Ude, 672 pp. [In Russian]. URL: http://ashipunov.info/shipunov/school/books/opred rast burjatii 2001.pdf

- Brianskaia E, Sandanov D, Li Y, Wang Z (2021) Distribution of alpine endemic plants of northern Asia: a dataset. Biodiversity Data Journal 9[In English]. https://doi.org/10.3897/ BDJ.9.e75348

- Chepinoga VV, Stepantsova NV, Grebenjuk AV, Verkhozina AV, et al. (2008) Конспект флоры Иркутской области (сосудистые растения). [Check-list of the vascular flora of the Irkutsk region]. Publishing house of the Irkutsk State University, Irkutsk, 327 pp. [In Russian]. [ISBN 978-5-9624-0311-3]

- Chepinoga VV, Petukhin VA, Stalmakova DP (2017a) Grid maps of the compendium "Flora of Central Siberia" (1979) in digital format: outcomes and prospects of application. Растительный мир Азиатской России 3 (27): 70-78. [In Russian]. https://doi.org/10.21782/RMAR1995-2449-2017-3(70-78) 
- Chepinoga VV, Protopopova MV, Pavlichenko VV (2017b) Detection of the most probable pleistocene microrefugia on the northern macroslope of the Khamar-Daban Ridge (Southern Prebaikalia). Contemporary Problems of Ecology 10 (1): 38-42. [In English]. https://doi.org/10.1134/S1995425517010036

- Chepinoga VV, Lashchinskiy NN, Arbusova GA, Gladkikh EM (2019) New and rare plant species on the Khamar-Daban Range (south of Eastern Siberia). Turczaninowia 22 (2): 151-159. [In Russian]. https://doi.org/10.14258/turczaninowia.22.2.11

- $\quad$ Epova NA (1956) Relics of tertiary broad-leaved forests in the Siberian fir (Abies sibirica ) taiga woods of Khamar-Daban. Известия Биолого-Географического НаучноИсследовательского Института при Иркутском Государственном Университетете Имени А.А. Жданова [News of Research Institute of Geography and Biology of A.A. Zhdanov Irkutsk State University] 16 (1-4): 25-61. [In Russian].

- Epova NA (1957) Materials on the characterization of the alpine meadows of KhamarDaban (preliminary report). Известия Биолого-Географического НаучноИсследовательского Института при Иркутском Государственном Университетете Имени А.А. Жданова [News of Research Institute of Geography and Biology of A.A. Zhdanov Irkutsk State University] 17 (1-4): 12-57. [In Russian].

- Epova NA (1960) Experience of fractional geobotanical zoning of Khamar-Daban (southern part of Central Siberia). In: Baranov PA, et al. (Ed.) Problems of botany. Materials for the study of flora and vegetation of highlands. 5. Academy of Sciences of USSR, Moscow-Leningrad, 47-61 pp. [In Russian].

- $\quad$ Epova NA (1961) To the characterization of the Siberian fir (Abies sibirica) taiga forests of Khamar-Daban. Труды Бурятского Комплексного Научно-Исследовательского Института Сибирского отделения Академии наук СССР, Серия Биолого-Почвенная [Proceedings of Buryat Integrated Research Institute of Siberian Branch of Academy of Sciences of USSR. Biology and Soil Series] (4)141-163. [In Russian].

- $\quad$ Erst AS, Sukhorukov AP, Mitrenina EY, Skaptsov MV, Kostikova VA, Chernisheva OA, Troshkina VI, Kushunina M, Krivenko DA, Ikeda H, Xiang K, W. W (2020) An integrative taxonomic approach reveals a new species of Eranthis (Ranunculaceae) in North Asia. PhytoKeys 140: 75-100. https://doi.org/10.3897/phytokeys.140.49048

- Gamova NS, Dudov SV (2012) Carex laevissima Nakai - new species for the Siberian flora and other new data about flora of the Baikalsky reserve. Turczaninowia 15 (2): 49-50. [In Russian]. URL: https://istina.msu.ru/download/12119869/1mZBFv:s6RS3u C2CBkfJLowDpNb3vTmwIM/

- Gamova NS, Krasnopevtseva AS (2013) Floristic findings in the Baikalsky Reserve. Turczaninowia 16 (4): 16-18. [In Russian]. URL: https://istina.msu.ru/download/ 11518130/1mZBHi:5Y9bsXor-JFI6Q61rkWFvxZB2YYI

- Gamova NS, Dudov SV (2018a) Floristic findings in Baikalsky reserve and its protective zone. Proceedings of the Mordovia State Nature Reserve 20: 15-23. [In Russian].

URL: https://istina.msu.ru/download/102222001/1mZBmt:tyVeXR6TEYPH MPWfASe9dPiqzb8/

- Gamova NS, Dudov SV (2018b) Additions to the flora of Baikal Nature Reserve. Turczaninowia 21 (3): 21-28. [In Russian]. https://doi.org/10.14258/turczaninowia.21.3.3

- Gamova NS, Chepinoga VV, Dudov SV, Serebryanyi MM (2018a) Floristic records in Southern part of Baikal region. Bulletin of Moscow Society of Naturalists. Biological series 123 (6): 69-71. [In Russian]. URL: https://istina.msu.ru/download/161482628/ $1 \mathrm{mZBfl}: M D U S K A g V a m i m-G F e t Z t K a D n Z I r s /$ 
- $\quad$ Gamova NS, Dudov SV, Sutkin AV, Krasnopevtseva AS (2018b) New and rarely found in Buryatia taxa of adventive plants from the buffer zone of the Baikal Nature Reserve. Turczaninowia 21 (3): 12-20. [In Russian]. https://doi.org/10.14258/turczaninowia.21.3.2

- Gamova NS, Kazanovsky SG, Anenkhonov OA, Tupitsyna NN, Olonova MV, Yurtzeva OV (2019) Cotoneaster lucidus Schltdl., Epipactis helleborine L. and another new records from the Baikalsky reserve. In: Gamova NS, Shekhovtsov Al, Kitaev AV (Eds) Role of scientific research in management and developement of special protected natural areas. Proceedings of scientific conference dedicated to 50th anniversary of Baikalsky Reserve. Role of scientific research in management and developement of special protected natural areas, Tankhoy, Republic of Buryatia, Russia, October 14-15, 2019. V.B. Sochava Institute of Geography SB RAS, Irkutsk, 74-83 pp. [In Russian]. URL: https://istina.msu.ru/download/254722477/1mZBxr:4L7ep64jmLZpn ljUF QINY1jyV4/

- Gamova NS (2021) Baikalsky State Nature Biosphere Reserve and its buffer zone: floristic data. 1.6. Lomonosov Moscow State University. Release date: 2021-11-25. URL: https://www.gbif.org/dataset/11512fe2-50cf-48e1-b681-3bb1f347eb86

- $\quad$ Gerasimov IP (Ed.) (1965) Предбайкалье и Забайкалье. [Cisbaicalia and Transbaicalia]. Nauka, Moscow, 492 pp. [In Russian].

- Ivanova MM (1967) Composition, features and some aspects of the genesis of the highmountain flora of Khamar-Daban (southern Baikal region). Научные Чтения Памяти М.Г. Попова [Scientific Lectures in Memory of M.G. Popov]49-79. [In Russian].

- Ivanova MM (1991) New findings in the flora of the Southern Transbaikalian region and of the Baikal region. Botanicheskii Zhurnal 76 (7): 1007-1016. [In Russian].

- Ivanova MM, Kazanovsky SG, Kiseleva AA (2016) New findings in the flora of the southeastern shore of the lake Baikal (region of Khamar-Daban mountain range): the nemoral relicts of tertiary flora and rare species. Turczaninowia 19 (3): 94-105. [In Russian]. https://doi.org/10.14258/turczaninowia.19.3.6

- Kartushin VM (1969) Агроклиматические ресурсы юга Восточной Сибири. [Agroclimatic resources of the south of Eastern Siberia]. Восточно-Сибирское книжное издательств, Irkutsk, 100 pp. [In Russian].

- Krasnopevtseva AS, Krasnopevtseva VM, Martusova EG (2008a) The news of vascular flora of the Baikalsky Reserve. Turczaninowia 11 (4): 47-49. [In Russian].

URL: http://old.ssbg.asu.ru/turcz/turcz4 $08 \quad 47 \quad 49 . p d f$

- Krasnopevtseva AS, Martusova EG, Krasnopevtseva VM (2008b) Кадастр сосудистых растений Байкальского государственного биосферного природного заповедника. [Cadastre of vascular plants of the Baikal State Biosphere Reserve]. Reprotsentr A1, Irkutsk, 60 pp. [In Russian].

- Krasnopevtseva AS, Krasnopevtseva VM (2012) New species in the flora of vascular plants of Baikal Reserve. In: Ananin AA, et al. (Ed.) History and perspectives of the Russian reserve management: problems of protection, scientific research and environmental education: Materials of the scientific-practical conference with international participation, dedicated to the 95th anniversary of the organization of the Barguzin State Natural Biosphere Reserve and the Year of Russian History. History and perspectives of the Russian reserve management: problems of protection, scientific research and environmental education, Ulan-Ude, Russia, August 22-24, 2012. Buryat State University, Ulan-Ude, 92-93 pp. [In Russian]. 
- $\quad$ Ladeishchikov NP, Filippov AH, Zedgenidze EG, Zusman IK, Obolkin VA, Reznikova S (1977) Осадки и режим увлажнения (Precipitation and moisture regime). In: Ladeishchikov NP, et al. (Ed.) Структура и ресурсы климата Байкала и сопредельных пространств (Structure and resources of climate of the Lake Baikal and adjacent territories). Nauka, Novosibirsk, 98-125 pp. [In Russian].

- $\quad$ Ogureeva GN, Miklyaeva IM, Safronova IN, Yurkovskaya TK (1999) Зоны и типы поясности растительности России и сопредельных территорий. Пояснительный текст и легенда к карте. [Zones and altitudinal zonality types of vegetation of Russia and adjacent territories]. Экор (Ekor), Moscow, 64 pp. [In Russian and English].

- Popov MG, Busik VV (1966) Конспект фрлоры побережий озера Байкал. [Conspectus florae litorum laci Baical]. Nauka, Moscow-Leningrad. [In Russian].

- Potapov, Zhuravleva, Yaroshenko, et al. (2021) Intact Forest Landscapes. http://intactforests.org/world.webmap.html. Accessed on: 2021-12-14.

- Seregin A (2021) Moscow University Herbarium (MW). 1.201. Lomonosov Moscow State University. Release date: 2021-11-06. URL: https://doi.org/10.15468/cpnhcc

- $\quad$ Sutkin AV, Martusova EG, Krasnopevtseva AS, Krasnopevtseva VM (2016) New data on alien vascular plants in Republic of Buryatia. Turczaninowia 19 (2): 82-85. [In Russian]. https://doi.org/10.14258/turczaninowia.19.2.11

- Sutkin AV, Krasnopevtseva AS (2020) New records of adventive vascular plants in Republic of Buryatia. Turczaninowia 23 (1): 110-115. [In Russian]. https://doi.org/ 10.14258/turczaninowia.23.1.11

- Takhtajan AL (1986) Floristic Regions of the World. University of California Press, 522 pp. [In English].

- $\quad$ Tjulina LN (1976) Влажный Прибайкальский тип поясности растительности. [Humid Baikalian type of vegetation zonation]. Nauka, Novosibirsk, 320 pp. [In Russian].

- Tupitsyna NN, Chepinoga VV (2016) Inventory of Hawkweeds (Hieracium and Pilosella, Asteraceae) in Baikal Siberia. Turczaninowia 19 (3): 73-87. [In Russian]. https://doi.org/ 10.14258/turczaninowia.19.3.4

- Unesco World Heritage Center (2021) Unesco World Heritage Center. http://whc.unesco.org/. Accessed on: 2021-11-25.

- Vasilchenko ZA, Ivanova MM, Kiseleva AA (1978) Overview of species of higher plants of the Baikal Nature Rererve. In: Malyschev LI, Peschkova GA (Eds) Flora of Cisbaikalia. Nauka, Novosibirsk, 49-114 pp. [In Russian]. URL: http://ashipunov.info/ shipunov/school/books/flora_pribajkalja_1978.djvu

- Verkhozina AV, Kazanovsky SG, Stepantsova NV, Krivenko DE (2013) Floristic findings in the republic of Buryatia and Irkutsk region. Turczaninowia 16 (3): 44-52. [In Russian]. https://doi.org/10.14258/turczaninowia.16.3.8

- Volotovsky KA, Ermolenko ED (1985) Addition to the flora of vascular plants of Baikalsky State Reserve. Herald of Kharkiv University (269)22-24. [In Russian]. 